OPEN ACCESS

Edited by:

Krish Seetah,

Stanford University, United States

Reviewed by:

Robert A. Dull,

California Lutheran University,

United States

Simon Haberle,

Australian National University,

Australia

Brooke Crowley,

University of Cincinnati, United States

*Correspondence:

Sergio Tofanell

sergio.tofanelli@unipi.it

Specialty section:

This article was submitted to

Paleoecology,

a section of the journal

Frontiers in Ecology and Evolution

Received: 11 May 2021

Accepted: 30 December 2021

Published: 20 January 2022

Citation:

Tofanelli S, Bertoncini S and Donati G (2022) Early Human Colonization, Climate Change

and Megafaunal Extinction

in Madagascar: The Contribution

of Genetics in a Framework

of Reciprocal Causations.

Front. Ecol. Evol. 9:708345

doi: $10.3389 /$ fevo.2021.708345

\section{Early Human Colonization, Climate Change and Megafaunal Extinction in Madagascar: The Contribution of Genetics in a Framework of Reciprocal Causations}

\author{
Sergio Tofanelli1,2*, Stefania Bertoncini ${ }^{1}$ and Giuseppe Donati ${ }^{3}$ \\ 'Dipartimento di Biologia, University of Pisa, Pisa, Italy, ${ }^{2}$ CIRSEC, Center for Climate Change Impact, University of Pisa, \\ Pisa, Italy, ${ }^{3}$ Department of Social Sciences, Oxford Brookes University, Oxford, United Kingdom
}

Keywords: Madagascar, human impacts, megafauna extinction, climate change, effective population size $\left(\mathrm{N}_{\mathrm{e}}\right)$, markovian coalescent methods

\section{INTRODUCTION}

The extinction of the megafauna in Madagascar and surrounding archipelagos (Seychelles, Comoro, and Mascarene islands) has been associated with evidence of ecological transformations, explained either by the increase of human activities (Hixon et al., 2018, 2021; Douglass et al., 2019; Godfrey et al., 2019; Railsback et al., 2020) or hydroclimatic shifts (Virah-Sawmy et al., 2009; Quéméré et al., 2012) or a combination of both (Salmona et al., 2017; Li et al., 2020; Teixeira et al., 2021). Whereas the Mascarenes lost their large-bodied endemic species within two centuries, in close association with human arrival (1638-1691 CE), in Madagascar the process has been estimated to be far slower, over a period of two millennia from 2,400 to $500 \mathrm{cal}$ yBP (Godfrey et al., 2019). The temporal overlap of climate- and human-induced impact makes it challenging to discern primary from secondary causes (Burney et al., 2004; Crowley, 2010). Thus, any ultimate assessment would need an understanding of the phases of human occupation coupled with a finer temporal resolution of regional climate and ecological variability.

Over the last few years, the question has been addressed by contributions from a wide spectrum of disciplines, of which genetics and genomics are among the most promising (e.g., Quéméré et al., 2012; Williams et al., 2020). The results show a complex web of relationships between possible causal factors. These findings offer the opportunity to reconsider both human and climatic factors as agents that can trigger ecological outcomes through processes of direct and indirect causal chains.

\section{THE DIALECTIC HUMAN/CLIMATIC FACTORS}

The earliest dates for human activities in Madagascar span from $>10,500$ to $1,350 \mathrm{cal} y \mathrm{yP}$ (radiocarbon calibrated years before present) (Burney et al., 2004; Muldoon, 2010; Dewar and Richard, 2012; Anderson et al., 2018; Hansford et al., 2018; Douglass et al., 2019). There is uncertainty about the oldest evidence (bone remains of elephant birds and pygmy hippos), variously 
interpreted as either butchery cutmarks or post-mortem artifacts (see Mitchell, 2019). Nonetheless, early sporadic presence of hunter/foragers in north-western and southern Madagascar cannot be definitively excluded. Artifacts more clearly associated with human activities appeared about 2,000 cal yBP (Burney et al., 2003, but see also Douglass et al., 2019; Mitchell, 2019), pointing to a more stable presence. However, the scarcity of extensive human-faunal interplay (hunting sites, butchery tools, and abundant cutmarks) and the limited number of non-native species introduced suggest a negligible ecological impact of these earlier incomers (Gommery et al., 2011).

Unambiguous evidence of a human demographic transition, driven by a massive immigration of Austronesian-speaking people from island Southeast Asia (Adelaar, 2009; Tofanelli et al., 2009; Tofanelli and Bertoncini, 2010; Cox et al., 2012; Crowther et al., 2016; Pierron et al., 2017; Anderson et al., 2018), can be reconstructed from post-1,300 cal yBP archeological remains, distributed in all the Malagasy ecoregions and the Comoros (Cox et al., 2012; Crowther et al., 2016; Anderson et al., 2018; Godfrey et al., 2019). The transition likely represented a cut-off between a regime of minimal ecological impact and a phase of intensive exploitation of natural resources due to the inclusion of Madagascar and the surrounding islands in the maritime trade network around the Indian Ocean rim.

Reconstructions of climate shifts based on speleothem and sediment analyses are consistent with these dates. The time when $\delta^{13} \mathrm{C}$ and $\delta^{18} \mathrm{O}$ isotope trends decoupled is used as a proxy to disentangle anthropogenic and climate effects. Investigations of stalagmites at Anjohibe Cave in northwestern Madagascar are eloquent (Burns et al., 2016; Wang et al., 2019; Railsback et al., 2020). They suggest a rapid increase in $\delta^{13} \mathrm{C}$ values not correlated to a simultaneous growth in $\delta^{18} \mathrm{O}$ values from by $1,300 \mathrm{cal} y B$. This is interpreted as a replacement of $\mathrm{C} 3$ forests with $\mathrm{C} 4$ grasslands and soil erosion possibly related to the practice of "burning horticulture," under steady humidity conditions. In certain regional contexts, reductions in forest coverage correlate temporally with mutually related variables, such as the pace of megafauna demographic decline (Godfrey et al., 2019; Hixon et al., 2021), human population growth and the introduction of domesticated species (Joseph and Seymour, 2020).

More questionable are the possible anthropogenic causes of the faunal decline (involving among others Palaeopropithecus, Archaeolemur, Megadalapis, Hadropithecus, Mesopropithecus, Pachylemur, and Hippopotamus sp.) that occurred in different ecoregions a 1,000 years $(2,400-1,300 \mathrm{yBP})$ before the first evidence of a stable colonization (Crowley, 2010; Anderson et al., 2018; Hansford et al., 2018; Godfrey et al., 2019; Faina et al., 2021; Hixon et al., 2021).

During the Early/Middle Holocene the Malagasy megafauna showed resilience to prolonged drought events, which changed habitats in terms of vegetation coverage and water regime (Burney et al., 2004; Quéméré et al., 2012; Wang et al., 2019). In particular, the 5,200 and 4,200 cal yBP aridity peaks are well defined in northwestern Madagascar (Wang et al., 2019). However, at no time was the entire island affected by massive natural drought, due to the antiphase between the north-west and the central and south (Wang et al., 2019). In contrast, the Late Holocene shows the culmination of a millennialscale drying trend with major aridity peaks between 2,000 and $500 \mathrm{cal} y \mathrm{yP}$ in different regions (Virah-Sawmy et al., 2010; Li et al., 2020). At Asafora Cave in the southwest stable carbon and oxygen isotope trends are coupled and suggest increasing CAM/C4 plant coverage and aridification between 3,320 and 880 yBP (Faina et al., 2021). Other lines of evidence support a scenario of a highly fluctuating landscape with a mosaic of grassy biomes and forested habitats at different altitudes and a diversity of endemic grass species spanning millennia (Bond et al., 2008; Vorontsova et al., 2016; Yoder et al., 2016; Samonds et al., 2019; Solofondranohatra et al., 2020; Crowley et al., 2021). This questions the dichotomy between natural and anthropogenic transformation of modern grasslands and the extent of the indirect role of humans (use of fire, introduction of domesticated species) in triggering megaherbivore decline.

A reliable scenario should not disregard the long-standing relationships among droughts, plant communities, natural fires, and mega-herbivores (elephant birds, giant lemurs, giant tortoises, and hippopotami) that pre-dated human arrival (Samonds et al., 2019).

\section{DISCUSSION}

Speleothems and sediments are not the only source of past environmental transformations. Biological systems are intimately related to their habitats and, when investigated in appropriate contexts, they become archives of the major changes that have occurred. From this perspective, the genomes of living and subfossil animals retain signs of demographic fluctuations that may be interpreted under model-free and model-based parameters to infer either the human impact on wild fauna (Frantz et al., 2016; Pujolar et al., 2017) or the effect of climate changes on population size and structure (Kozma et al., 2018; Miller et al., 2021; Song et al., 2021).

The effective population size $\mathrm{N}_{\mathrm{e}}$ is a key parameter in ecology and conservation biology. In one of its most widely used forms, it infers the size of an idealized population (Wright-Fisher) which, through inbreeding and/or genetic drift, underwent the same loss of genetic diversity observed in the population under study. There are many ways to genetically estimate $\mathrm{N}_{\mathrm{e}}$ and important theoretical advances have recently been made in this field (e.g., Husemann et al., 2016; Hill and Baele, 2019). Widely used approaches test effective size declines under the statistical framework of the Coalescent Theory or the coalescent (Kingman, 1982; Wakeley, 2008). In this, the pairs of lineages of a sampled genealogy merging into an ancestral one while going backward in time (coalescence events) are compared with the expected rate of a modeled steady population: the more coalescence events, the smaller or more structured the population. Crossdisciplinary research teams have attempted to merge genetically based reconstructions of historic demography for Malagasy fauna with ecological and ethological evidence. For example, although the population size and range distribution of the extant 
large lemur Propithecus tattersalli is decreasing today, Quéméré et al. (2012) revealed, via bottleneck modeling, a population collapse much older than the likely arrival of humans in their current range (northern Madagascar). Similarly, Bertoncini et al. (2017) inferred habitat shifts from the genetic diversity of a medium-sized lemur (Eulemur collaris) living in south-eastern Madagascar (Rakotoarisoa, 1997; Virah-Sawmy et al., 2010). Genetic estimates of $\mathrm{N}_{e}$ and mitochondrial coalescence times depict a scenario of strong demographic contraction for Eulemur groups now separated by extended strips of grasslands and swamps. This is in line with an original condition of mixed woodland forest and a rapid transition to an open habitat dominated by ericoid grassland driven by marine surges before 700-1,500 cal yBP (Virah-Sawmy et al., 2009, 2010). Other studies detected recent bottlenecks in species from different regions over the island with a population decrease of approximately two orders of magnitude that occurred in the last millenium both in small nocturnal lemurs (Lepilemur edwardsi: Craul et al., 2008; Microcebus ravelobensis: Olivieri et al., 2007; Microcebus murinus and Microcebus ravelobensis: Teixeira et al., 2021) and larger diurnal lemurs (Lemur catta: Parga et al., 2012; Propithecus verreauxi: Lawler, 2008; Propithecus perrieri and Propithecus tattersalli, Salmona et al., 2017). Taken together, such studies depict more complex relationships between the candidate factors of faunal demise.

Given the endangered status of the Malagasy living fauna (Schwitzer et al., 2014), which makes non-invasive sampling a common practice, and the low quality of DNA from fossil remains (e.g., Dabney et al., 2013), approaches that maximize the reconstruction of demographic profiles from few low-coverage genomes are a priority. Methods combining hidden Markovian chains and the coalescent (PSMC, Pairwise Sequentially Li and Durbin, 2011; MSMC, Multiple Sequentially Markovian Coalescent, Schiffels and Durbin, 2014) allow millennial timeseries of population size/structure fluctuations to be obtained to support evidence of past ecological shifts even from a single specimen (Stoneking, 2017). Ideally, the graphs based on the Markovian coalescent approaches represent more exhaustive indicators of extinction dynamics than the extent of the skeletal record.

To date PSMC has been applied to whole genomic data from hibernating dwarf lemurs (Cheirogaleus medius, C. major, C. crossleyi, and C. sibreei, Williams et al., 2020) and mouse lemurs (Microcebus murinus, M. ravelobensis, Teixeira et al., 2021). In the former study, evidence for a slow decline in the last 50,000 years, long before the arrival of any human beings on the island, was found. Long-term reductions in $\mathrm{N}_{\mathrm{e}}$ and low heterozygosity may have heavily affected the survival of dwarf lemurs due to inbreeding depression, namely the expression of detrimental genes or the scanty diversity across immune genes (Morris et al., 2015; Rogers and Slatkin, 2017). Interestingly, a less fluctuating $\mathrm{N}_{\mathrm{e}}$ was estimated in the genome of $C$. sibreei, the only species adapted to high-altitude habitats, consistent with the paleoecological evidence of more stable habitats in the Central Highlands
(Wilmé et al., 2006; Samonds et al., 2019). It can be argued that climatic pulsing exerted more extreme demographic consequences on low-altitude species, which likely experienced greater levels of habitat fragmentation, vegetation shifts, cyclones, and marine transgressions/tsunami. These climatic shifts have been hypothesized to be frequent during the Quaternary and used to explain the remarkable process of speciation on the island (Wilmé et al., 2006).

\section{CONCLUSION}

Whether humans or climatic shifts are the primary source that triggered the megafaunal extinction in Madagascar is still highly questioned. There is general convergence upon the fundamental role that the demographic growth of Austronesian colonizers and their introduction of subsistence agriculture had played in the over-exploitation of natural resources by around 1,300 yBP (e.g., Crowther et al., 2016; Anderson et al., 2018; Godfrey et al., 2019). There is also growing evidence of complex climate-driven shifts in geological and biological archives that suggests a move away from the narrative of human/climate duality and toward a paradigm of mutual rather than distinct causality (Salmona et al., 2017; Li et al., 2020). To further complicate the picture, the relative contribution of multiple drivers of change appears to vary among the regions of the island depending on the local climate, the faunal/vegetational assemblages and the pattern of human settlement (e.g., Virah-Sawmy et al., 2010; Yoder et al., 2016; Wang et al., 2019; Railsback et al., 2020; Teixeira et al., 2021). We hope that an increase in cross-disciplinary research will help to clarify whether historical human colonization of Madagascar and neighboring archipelagos were facilitated by a long-term biotic stress experienced by endemic megafauna. From this perspective, genomes of both living and extinct taxa, at either individual or population level, need to be explored more extensively as repositories of past demographic trends closely associated with changing ecosystems.

\section{AUTHOR CONTRIBUTIONS}

ST wrote the manuscript. SB and GD contributed to the interpretation and the revision of the work. All authors contributed to the article and approved the submitted version.

\section{FUNDING}

This work was supported by the University of Pisa ex60\% Grants.

\section{ACKNOWLEDGMENTS}

We are very grateful to Claire Cardinal for her linguistic revision and to the reviewers for their fruitful contribution. 


\section{REFERENCES}

Adelaar, A. (2009). “Towards an integrated theory about the Indonesian migrations to Madagascar," in Ancient Human Migrations: An Interdisciplinary Approach, eds P. N. Peregrine, I. Peiros, and M. Feldman (Salt Lake City, UT: University of Utah Press).

Anderson, A., Camens, A., Clark, G., and Haberle, S. (2018). "Investigating premodern colonization of the Indian Ocean: the remote islands enigma," in Connecting Continents: Archaeology and History in the Indian Ocean World, ed. K. Seetah (Athens: Ohio University Press), 30-67.

Bertoncini, S., D’Ercole, J., Brisighelli, F., Ramanamanjato, J. B., Capelli, C., Tofanelli, S., et al. (2017). Stuck in fragments: population genetics of the Endangered collared brown lemur Eulemur collaris in the Malagasy littoral forest. Am. J. Phys. Anthropol. 163, 542-552. doi: 10.1002/ajpa.23230

Bond, W. J., Silander, J. A. Jr., Ranaivonasy, J., and Ratsirarson, J. (2008). The antiquity of Madagascar's grasslands and the rise of $\mathrm{C} 4$ grassy biomes. J. Biogeogr. 35, 1743-1758.

Burney, D. A., Burney, L. P., Godfrey, L. R., Jungers, W. L., Goodman, S. M., Wright, H. T., et al. (2004). A chronology for late prehistoric Madagascar. J. Hum. Evol. 47, 25-63. doi: 10.1016/j.jhevol.2004.05.005

Burney, D. A., Robinson, G. S., and Burney, L. P. (2003). Sporormiella and the late Holocene extinctions in Madagascar. Proc. Natl. Acad. Sci. U.S.A. 100, 10800-10805. doi: 10.1073/pnas.1534700100

Burns, S. J., Godfrey, L. R., Faina, P., McGee, D., Hardt, B., Ranivoharimanana, L., et al. (2016). Rapid human-induced landscape transformation in Madagascar at the end of the first millennium of the common era. Quat. Sci. Rev. 134:92e99.

Cox, M. P., Nelson, M. G., Tumonggor, M. K., Ricaut, F. X., and Sudoyo, H. (2012). A small cohort of island Southeast Asian women founded Madagascar. Proc. Biol. Sci. 279, 2761-2768. doi: 10.1098/rspb.2012.0012

Craul, M., Radespiel, U., Rasolofoson, D. W., Rakotondratsimba, G., Rakotonirainy, O., Rasoloharijaona, S., et al. (2008). Large rivers do not always act as species barriers for Lepilemur sp. Primates 49, 211-218.

Crowley, B. E. (2010). A refined chronology of prehistoric Madagascar and the demise of the megafauna. Quat. Sci. Rev. 29, 2591-2603. doi: 10.1016/j. quascirev.2010.06.030

Crowley, B. E., Godfrey, L. R., Hansford, J. P., and Samonds, K. E. (2021). Seeing the forest for the trees-and the grasses: revisiting the evidence for grazermaintained grasslands in Madagascar's Central Highlands. Proc. R. Soc. B 288:20201785. doi: 10.1098/rspb.2020.1785

Crowther, A., Lucas, L., Helm, R., Horton, M., Shipton, C., Wright, H. T., et al. (2016). Ancient crops provide first archaeological signature of the westward Austronesian expansion. Proc. Natl. Acad. Sci. U.S.A. 113:6635e6640. doi: 10. 1073/pnas.1522714113

Dabney, J., Meyer, M., and Pääbo, S. (2013). Ancient DNA damage. Cold Spring Harb. Perspect. Biol. 5:a012567.

Dewar, R. E., and Richard, A. F. (2012). Madagascar: a history of arrivals, what happened, and will happen next. Annu. Rev. Anthropol. 41:495e517.

Douglass, K., Hixon, S., Wright, H. T., Godfrey, L. R., Crowley, B. E., Manjakahery, B., et al. (2019). A critical review of radiocarbon dates clarifies the human settlement of Madagascar. Quat. Sci. Rev. 221:105878.

Faina, P., Burns, S. J., Godfrey, L. R., Crowley, B. E., Scroxton, N., McGee, D., et al. (2021). Comparing the paleoclimates of northwestern and southwestern Madagascar during the late Holocene: implications for the role of climate in megafaunal extinction. Malagasy Nat. 15, 108-127.

Frantz, L. A., Mullin, V. E., Pionnier-Capitan, M., Lebrasseur, O., Ollivier, M., Perri, A., et al. (2016). Genomic and archaeological evidence suggest a dual origin of domestic dogs. Science 352, 1228-1231.

Godfrey, L. R., Scroxton, N., Crowley, B. E., Burns, S. J., Sutherland, M. R., Pérez, V. R., et al. (2019). A new interpretation of Madagascar's megafaunal decline: the "subsistence shift hypothesis". J. Hum. Evol. 130, 126-140.

Gommery, D., Ramanivosoa, B., Faure, M., Guérin, C., Kerloc’h, P., Sénégas, F., et al. (2011). Les plus anciennes traces d'activités anthropiques de Madagascar sur des ossements d'hippopotames subfossiles d'Anjohibe (Province de Mahajanga). Comptes Rendus Palevol 10, 271-278.

Hansford, J., Wright, P. C., Rasoamiaramanana, A., Pérez, V. R., Godfrey, L. R., Errickson, D., et al. (2018). Early Holocene human presence in Madagascar evidenced by exploitation of avian megafauna. Sci. Adv. 4:eaat6925.
Hill, V., and Baele, G. (2019). Bayesian estimation of past population dynamics in BEAST 1.10 using the Skygrid coalescent model. Mol. Biol. Evol. 36, 2620-2628.

Hixon, S. W., Douglas, K. G., Crowley, B. E., Rakotozafy, L. M. A., Clark, G., Anderson, A., et al. (2021). Late Holocene spread of pastoralism coincides with endemic megafaunal extinction on Madagascar. Proc. R. Soc. B 288:20211204.

Hixon, S. W., Elliott Smith, E. A., Crowley, B. E., Perry, G. H., Randrianasy, J., Ranaivoarisoa, J. F., et al. (2018). Nitrogen isotope $(\delta 15 N)$ patterns for amino acids in lemur bones are inconsistent with aridity driving megafaunal extinction in south-western Madagascar. J. Quat. Sci. 33, 958-968.

Husemann, M., Zachos, F. E., Paxton, R. J., and Habel, J. C. (2016). Effective population size in ecology and evolution. Heredity (Edinb) 117, 191-192.

Joseph, G. S., and Seymour, C. L. (2020). Madagascan highlands: originally woodland and forest containing endemic grasses, not grazing-adapted grassland. Proc. R. Soc. B 287:20201956.

Kingman, J. F. C. (1982). The coalescent. Stoch. Process. Their Appl. 13, 235-248.

Kozma, R., Lillie, M., Benito, B. M., Svenning, J. C., and Höglund, J. (2018). Past and potential future population dynamics of three grouse species using ecological and whole genome coalescent modeling. Ecol. Evol. 8, 6671-6681.

Lawler, R. R. (2008). Testing for a historical population bottleneck in wild Verreaux's sifaka (Propithecus verreauxi verreauxi) using microsatellite data. Am. J. Primatol. 70, 990-994.

Li, H., and Durbin, R. (2011). Inference of human population history from individual whole-genome sequences. Nature 475, 493-496.

Li, H., Sinha, A., André, A. A., Spötl, C., Vonhof, H. B., Meunier, A., et al. (2020). A multimillennial climatic context for the megafaunal extinctions in Madagascar and Mascarene Islands. Sci. Adv. 6:eabb2459.

Miller, D. A. W., Brehme, C. S., Hines, J. E., Nichols, J. D., and Fisher, R. N. (2021). Joint estimation of habitat dynamics and species interactions: disturbance reduces co-occurrence of non-native predators with an endangered toad. J. Anim. Ecol. 81, 1288-1297.

Mitchell, P. (2019). Settling Madagascar: when did people first colonize the world's largest island? J. Island Coast. Archaeol. 15, 576-595.

Morris, K. M., Wright, B., Grueber, C. E., Hogg, C., and Belov, K. (2015). Lack of genetic diversity across diverse immune genes in an endangered mammal, the Tasmanian devil (Sarcophilus harrisii). Mol. Ecol. 24, 3860-3872.

Muldoon, K. M. (2010). Paleoenvironment of Ankilitelo cave (late Holocene, southwestern Madagascar): implications for the extinction of giant lemurs. J. Hum. Evol 58:338e352.

Olivieri, G., Zimmermann, E., Randrianambinina, B., Rasoloharijaona, S., Rakotondravony, D., Guschanski, K., et al. (2007). The ever-increasing diversity in mouse lemurs: three new species in north and northwestern Madagascar. Mol. Phylogenet. Evol. 43, 309-327.

Parga, J. A., Sauther, M. L., Cuozzo, F. P., Jacky, I. A. Y., and Lawler, R. R. (2012). Evaluating ring-tailed lemurs (Lemur catta) from southwestern Madagascar for a genetic population bottleneck. Am. J. Phys. Anthropol. 147, 21-29.

Pierron, D., Heiske, M., Razafindrazaka, H., Rakoto, I., Rabetokotany, N., Ravololomanga, B., et al. (2017). Genomic landscape of human diversity across Madagascar. Proc. Natl. Acad. Sci. U.S.A. 114, E6498-E6506.

Pujolar, J. M., Dalén, L., Hansen, M. M., and Madsen, J. (2017). Demographic inference from whole-genome and RAD sequencing data suggests alternating human impacts on goose populations since the last ice age. Mol. Ecol. 26, 6270-6283.

Quéméré, E., Amelot, X., Pierson, J., Crouau-Roy, B., and Chikhi, L. (2012). Genetic data suggest a natural prehuman origin of open habitats in northern Madagascar and question the deforestation narrative in this region. Proc. Natl. Acad. Sci. U.S.A. 109, 13028-13033.

Railsback, L. B., Dupont, L. A., Liang, F., Brook, G. A., Burney, D. A., Cheng, H., et al. (2020). Relationships between climate change, human environmental impact, and megafaunal extinction inferred from a 4000-year multi-proxy record from a stalagmite from northwestern Madagascar. Quat. Sci. Rev. 234:106244.

Rakotoarisoa, J. (1997). "A cultural history of Madagascar. Evolution and interpretation of the archeological record," in Natural Change and Human Impact in Madagascar, eds S. K. Goodman and B. D. Patterson (Washington, DC: Smithsonian Institution Press), 331-341. 
Rogers, R. L., and Slatkin, M. (2017). Excess of genomic defects in a woolly mammoth on Wrangel island. PLoS Genet. 13:e1006601. doi: 10.1371/journal. pgen.1006601

Salmona, J., Heller, R., Quéméré, E., and Chikhi, L. (2017). Climate change and human colonization triggered habitat loss and fragmentation in Madagascar. Mol. Ecol. 26, 5203-5222.

Samonds, K. E., Crowley, B. E., Rasolofomanana, T. R., Andriambelomanana, M. C., Andrianavalona, H. T., Ramihangihajason, T. N., et al. (2019). A new late Pleistocene subfossil site (Tsaramody, Sambaina basin, central Madagascar) with implications for the chronology of habitat and megafaunal community change on Madagascar's Central Highlands. J. Quat. Sci. 34, 379-392.

Schiffels, S., and Durbin, R. (2014). Inferring human population size and separation history from multiple genome sequences. Nat. Genet. 46, 919-925.

Schwitzer, C., Mittermeier, R. A., Johnson, S. E., Donati, G., Irwin, M., Peacock, H., et al. (2014). Averting lemur extinctions amid Madagascar's political crisis. Science 343, 842-843.

Solofondranohatra, C. L., Vorontsova, M. S., Hempson, G. P., Hackel, J., Cable, S., Vololoniaina, J., et al. (2020). Fire and grazing determined grasslands of central Madagascar represent ancient assemblages. Proc. Biol. Sci. 287:20200598.

Song, K., Gao, B., Halvarsson, P., Fang, Y., Klaus, S., Jiang, Y. X., et al. (2021). Demographic history and divergence of sibling grouse species inferred from whole genome sequencing reveal past effects of climate change. BMC Ecol. Evol. 21:194. doi: 10.1186/s12862-021-01921-7

Stoneking, M. (2017). An Introduction to Molecular Anthropology. Hoboken, NJ: Wiley Blackwell, 193.

Teixeira, H., Montade, V., Salmona, J., Metzger, J., Bremond, L., Kasper, T., et al. (2021). Past environmental changes affected lemur population dynamics prior to human impact in Madagascar. Commun. Biol. 4:1084.

Tofanelli, S., and Bertoncini, S. (2010). "Origin and evolutionary history of the Malagasy," in Encyclopedia of Life Sciences, ed. John Wiley \& Sons, Ltd. (Chichester: John Wiley \& Sons), doi: 10.1002/9780470015902.a00 22885

Tofanelli, S., Bertoncini, S., Castrì, L., Luiselli, D., Calafell, F., Donati, G., et al. (2009). On the origins and admixture of Malagasy: new evidence from highresolution analyses of paternal and maternal lineages. Mol. Biol. Evol. 26, 2109-2124.

Virah-Sawmy, M., Willis, K. J., and Gillson, L. (2009). Threshold response of Madagascar's littoral forest to sea-level rise. Glob. Ecol. Biogeogr. 18, $98-110$.
Virah-Sawmy, M., Willis, K. J., Gillson, L., and Williams, J. (2010). Evidence for drought and forest declines during the recent megafaunal extinctions in Madagascar. J. Biogeogr. 37, 506-519.

Vorontsova, M., Besnard, G., Forest, F., Malakasi, P., Moat, J., Clayton, W. D., et al. (2016). Madagascar's grasses and grasslands: anthropogenic or natural? Proc. Biol. Sci. 283:20152262. doi: 10.1098/rspb.2015.2262

Wakeley, J. (2008). Coalescent Theory. Greenwood Village, CO: Roberts \& Company.

Wang, L., Brook, G. A., Burney, D. A., Voarintsoa, N. R. G., Liang, F., Cheng, H., et al. (2019). The African Humid Period, rapid climate change events, the timing of human colonization, and megafaunal extinctions in Madagascar during the Holocene: evidence from a $2 \mathrm{~m}$ Anjohibe Cave stalagmite. Quat. Sci. Rev. 210, 136-153.

Williams, R. C., Blanco, M. B., Poelstra, J. W., Hunnicutt, K. E., Comeault, A. A., and Yoder, A. D. (2020). Conservation genomic analysis reveals ancient introgression and declining levels of genetic diversity in Madagascar's hibernating dwarf lemurs. Heredity (Edinb) 124, 236-251. doi: 10.1038/s41437019-0260-9

Wilmé, L., Goodman, S. M., and Ganzhorn, J. U. (2006). Biogeographic evolution of Madagascar's microendemic biota. Science 312, 1063-1065. doi: 10.1126/ science. 1122806

Yoder, A. D., Campbell, C. R., Blanco, M. B., Dos Reis, M., Ganzhorn, J. U., Goodman, S. M., et al. (2016). Geogenetic patterns in mouse lemurs (genus Microcebus) reveal the ghosts of Madagascar's forests past. Proc. Natl. Acad. Sci. U.S.A. doi: 10.1073/pnas. 1601081113

Conflict of Interest: The authors declare that the research was conducted in the absence of any commercial or financial relationships that could be construed as a potential conflict of interest.

Publisher's Note: All claims expressed in this article are solely those of the authors and do not necessarily represent those of their affiliated organizations, or those of the publisher, the editors and the reviewers. Any product that may be evaluated in this article, or claim that may be made by its manufacturer, is not guaranteed or endorsed by the publisher.

Copyright (C) 2022 Tofanelli, Bertoncini and Donati. This is an open-access article distributed under the terms of the Creative Commons Attribution License (CC BY). The use, distribution or reproduction in other forums is permitted, provided the original author(s) and the copyright owner(s) are credited and that the original publication in this journal is cited, in accordance with accepted academic practice. No use, distribution or reproduction is permitted which does not comply with these terms. 